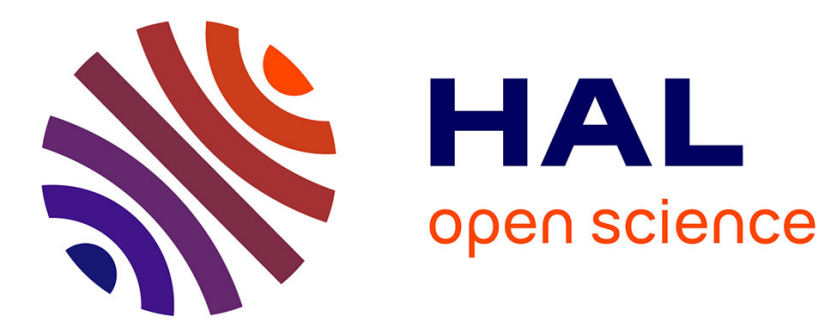

\title{
The dico form: An autonymous marker
}

Tatiana Taous

\section{- To cite this version:}

Tatiana Taous. The dico form: An autonymous marker. Journal of Latin Linguistics, 2017, 16 (2), pp.219-237. hal-03132227v1

\section{HAL Id: hal-03132227 https://hal-cyu.archives-ouvertes.fr/hal-03132227v1}

Submitted on 19 Feb 2021 (v1), last revised 16 Oct 2021 (v2)

HAL is a multi-disciplinary open access archive for the deposit and dissemination of scientific research documents, whether they are published or not. The documents may come from teaching and research institutions in France or abroad, or from public or private research centers.
L'archive ouverte pluridisciplinaire HAL, est destinée au dépôt et à la diffusion de documents scientifiques de niveau recherche, publiés ou non, émanant des établissements d'enseignement et de recherche français ou étrangers, des laboratoires publics ou privés. 


\title{
The Dico form: an autonymous marker.
}

\author{
TAOUS Tatiana \\ tatianataous@gmail.com \\ University of Nice - Sophia Antipolis (ESPE) \\ 59, Allée Emile Pratali \\ 83507 La Seyne-sur-mer cedex \\ The Alfred ERNOUT Center (EA 4080)
}

\begin{abstract}
Summary
In this paper we review a specific use of the dico form: its use as autonymous marker. From a corpus of Latin texts (from the archaic period to the Flavian Age), we try to determine if this use is correlated to specific linguistic configurations. After reminding that the dico form could be used in the self-quotation with different values (over-enunciative and autonymous) often connected with the morphosyntactic form of the quoted speech, we study more specifically the linguistic conditions of emergence of the dico form as autonymous marker and review different criteria: contextual, syntactic, semantic and pragmatic. In the last part of this paper, we propose to focus our attention on two phenomena, particularly relevant: the autodiaphonic repetitions and the case particularities of the word used in autonymy with dico.
\end{abstract}

Keywords: token-reflexivity, metadiscourse, enunciative disconnection, aspectual value, pragmatics.

\section{Introduction}

The notion of autonymy is relatively difficult to grasp. ${ }^{1}$ Indeed, if the use of autonymous units is a frequent phenomenon in languages, ${ }^{2}$ the conceptualization of this phenomenon is late and subject to discussion, evolution and precision. ${ }^{3}$ Since the end of the $19^{\text {th }}$ century, ${ }^{4}$ linguists and philosophers of language agree with the idea that the words of

\footnotetext{
${ }^{1}$ Brabanter (2005: 14-17) proposes a background to the notion and studies the problematic and chaotic emergence of terms as fr. autonymie, autonyme and emploi autonymique. In the English terminology, two stems are used at first: referent-/c- (see self-referential in Levinson's (1983: 254, note 17), Wales' (1989: 414) and Nöth's (1995 [1990]: 425) works; self-reference in Wales' (1989: 414) and Nöth's (1995 [1990]: 436) works) and reflex- (see reflexive in Lyons' (1977: 5 and note 3, 6, 55...) and Crystal's (2003: 392) works; tokenreflexivity in Lyons' (1977: 15) and Levinson's (1983: 57, 62, 86...) works; auto-reflexivity in Nöth's (1995 [1990]: 349, 358) and Colapietro's (1993:44) works). With respect to the first member of the compound, English uses self-, token- and auto-. The word autonymy is utilized by Nöth (1995 [1990]: 349) and Colapietro (1993: 44). See Bearth and Fennig (2015) and their French-English glossary of linguistic terms.

${ }^{2}$ Nicolas notices that the Latin writers very often use metalinguistic units (see Nicolas 2005a: 95) and that they readily utilize - as every speaker - the metalinguistic function (see Nicolas 2005b: 46). Despite the Augustine's intuitions about the autonymous uses of common (as uilla) or metalinguistic words (as uerbum), the reflection is not led to the end and does not come to a linguistic system (Nicolas 2005b: 47-55 et 70).

${ }^{3}$ We must wait for the philosophers of language, Frege (1994 [1892]), Carnap (2002 [1937]: 17, 153-156, 237, 250-253), and Quine (1981 [1940]), who will try to conceptualize the notion. With respect to the productivity and the interest of the discussion about the autonymy in linguistics, see Brabanter 2005: 29-40.

${ }^{4}$ But Augustine had recognized four uses: common uses (engl. The table is set), metalinguistic uses in usage (engl. In French the verb inflects), autonymous uses (engl. "The table" is set), autonymous uses with
} 
natural languages can be used in two ways in discourse: ${ }^{5}$ a "common" use, i. e. that the words are used in usage, with actualization of their meaning in language, and a "less common" use ("moins ordinaire", Brabanter 2005: 13) where, used in mention, the words play with the relation between signified and signifiant and so they belong to the metalanguage, and no longer to the language. ${ }^{6}$

In linguistics, the identification of autonymy represents a real difficulty and constitutes one of the major problems. The first theoreticians of autonymy (see Brabanter 2005: 14 and 18), and especially the followers of the demonstrative theory (see Brabanter 2005: 26-29), thought that the inverted commas were a relevant and decisive criterion in order to recognize a word used in autonymy. However the utilization of inverted commas is never systematic and reveals, in discourse, an "overt form of the shown heterogeneity"7 (Authier-Revuz 1984), but this discursive heterogeneity may also be hidden: so the interlocutor needs some sufficient knowledge in order to grasp the heterogeneity.

But even with overt heterogeneity, the inverted commas are not the only sign: to indicate an autonymous use, the speaker may use not only typographic signs, only visible with the written forms, like italics, inverted commas or red slashes of mediaeval manuscripts (see Rosier-Catach 2003: 2), but also morphological and syntactic signs, visible with written and spoken language. These signs belong to rules which are parallel (and sometimes conflicting) with grammatical rules of the common and usual language: ${ }^{8}$ in French, the utilization or the non-utilization of the determiner (see, in (1a) and (1b), the underlined units) disagrees with the syntax of usual clauses. ${ }^{9}$ In (1c), the inflectional form of the verb (fr. s'entend) depends neither on the number of the noun nor on the article with which it occurs. Also are selected the no-marked gender and number in French, i. e. masculine and singular. A similar phenomenon can be noticed about (1d): the speaker selects the masculine of the definite article, whereas the grammatical use requires the feminine with the French noun faucille. The utilization of comments in brackets or parenthetical and disjunct sentences is also a clear indication of the autonymous use, whereas the body language and the suprasegmental indications can play a very important role in this identification. ${ }^{10}$

(1)

a. fr. $\times$ Sieur est aujourd'hui hors d'usage.

b. fr. CES tu vois m'excèdent au plus au point.

metalinguistic words ("Verb" is a noun). See Rosier-Catach (2003: 6-7) and Nicolas (2005b: 47-50). The mediaeval copyists have also been sensitive to these uses where the word seems to be understood in its materiality. For a complete approach, see Rosier-Catach 2003.

5 That is Quine's opposition between "use" and "mention" (Quine 1981 [1940]: 23-27; see also Lyons 1977: 5$10)$.

${ }^{6}$ See, for example, Rey-Debove 1971: 90, Fleck 2015: 1.

7 "Une forme marquée de l'hétérogénéité montrée".

${ }^{8}$ Nicolas 2005a: 96, 2005b: 45.

${ }^{9}$ It is possible that the utilization of this determiner with the parts of speech, which commonly do not need it, is due to an "amazing" invention of mediaeval Latin of scholars ("une invention remarquable du latin savant médiéval"), indicated by Rosier-Catach (2003: 4-6): the French article $l i$ and its allomorphs are used in order to indicate an autonymous use; the French article is positioned before Latin words in hybrid phrases, like le homo / li homo (with a noun), del albus (with an adjective) or li legit (with an inflected verb).

${ }^{10}$ For example, we think about the "mimed" inverted commas which go with the speech of some speakers and indicate visually the autonymous use or, more generally, the discursive heterogeneity in the speech. 
c. fr. LES cagoles ne S'ENTEND qu'à Marseille et dans sa région.

d. fr. LE FAUCILLE d'or de Hugo (example from Rey-Debove's paper (1971: 91))

According to Rosier-Catach (2003: 2), "there are no univocal typographic or linguistic markers which allow recognizing autonymous uses". ${ }^{11}$ However, on the occasion of a colloquium dealing with the (in)direct speech act in Latin, we have worked on the selfquotation, indicated by the use of the forms of lexeme dico / aio and we have proposed a comparative and contrastive study of these verbal forms. But, unlike aio, the specificity of dico is that this verbal form can be considered a real autonymous marker. ${ }^{12}$ We have tried to explain this phenomenon, but it was impossible to develop the complete analysis. ${ }^{13}$ That is why, in this paper, we would like to work on the uses of dico as autonymous marker and add some indications about this verbal form, especially concerning the morphosyntactic and pragmatic behavior of this "overt form of the shown heterogeneity" (Authier-Revuz 1984).

\section{The verbal form dico in self-quotation}

\section{1. Self-quotation: definition}

A speaker may integrate alterity into his own utterance; this phenomenon is current in discourse. In the mind of the locutor, this integration may be deliberate and explicitly indicated: for example, by an explicit reference to the popular parole (the way of "comme on dit"), or by a reference to the individualized alterity (the way of "comme il/elle dit"). ${ }^{14}$ Discursive alterity may also be deliberate, but hidden; then, it may be involuntary: the locutor is so full of another speech that he does not know that he is quoting a speech which does not belong to him. ${ }^{15}$

In these three configurations, alterity is more or less consciously integrated by the speaker. Nevertheless there is another way of speaking: the way of "comme je dis" (ReyDebove 1971: 92). Quotation becomes "self-quotation". Rosier (2008: 126) defines selfquotation as a "quotation by oneself of an utterance which seems like an anterior or a socalled anterior utterance in the speech". ${ }^{16}$ When the Latin locutor is using the verbal formdico, he repeats his first utterance and stresses his own verbal act: he becomes his own repeater (see Taous 2016: 13-14). In this analysis of verbal form-dico, we have decided to consider a corpus from ancient Latin texts to neo-classical Latin texts (namely from the archaic period to the Flavian period), ${ }^{17}$ in order to propose a large view of configurations where dico can be used. ${ }^{18}$

\footnotetext{
11 "Il n'existe pas de marques typographiques ou linguistiques univoques des usages autonymiques".

${ }^{12}$ See also Rosier-Catach (2003: 5) and Nicolas (2005b: 49 and note 10).

${ }^{13}$ For this comparative work, see Taous 2016.

${ }^{14}$ See Rey-Debove (1971: 92) and the three ways of speaking: the way of "it is said", the way of "he/she says/is saying" and the way of "I say/am saying".

15 Concerning this idea that "necessarily, the words always are "the words of everyone"” (fr. "les mots sont toujours, inévitablement, 'les mots des autres"'), see Authier-Revuz 1984: 99-100.

16 “Citation par soi d'un dire qui se présente dans le discours comme un dire antérieur ou supposé tel”.

${ }_{18}^{17}$ For a periodization of Latin literature, see Flobert 1975 and the following note.

18 We have listed the Latin examples from Brepols' web site (see on http://clt.brepolis.net.janus.biu.sorbonne.fr/llta/Default.aspx, accessed 27 August 2013). The 444 examples of
} 


\section{2. Self-quotation with dico: parameters of analysis}

Locutors use the dico form in three configurations: (auto)diaphonic repetitions, ${ }^{19}$ emphatic contexts (in (2), see At ego, tu, nunc) and contrastive contexts (in (2c), see percipe vs dico): ${ }^{20}$

(2)

a. Plt. Poen. 472-474:

AN. ... sexaginta milia HOMINVM uno die

VOLATICORVM manibus occidi meis.

LY. VOLATICORVM HOMINVM? AN. Ita deico quidem.

b. Plt. Amph. 612-613:

SO. AT EGO NVNC, Amphitruo, dico: Sosiam seruom tuom

praeter me alterum, inquam, adueniens faciam ut offendas domi

c. Lucr. III 135-136:

... TV cetera percipe dicta.

NVNC animum atque animam dico coniuncta teneri.

Nevertheless, in these three examples, the dico form must not be considered as an autonymous marker: its utilization indicates that the speaker reaffirms his posture of locutor in his utterance act. So the morphosyntactic class of the quoted unit, introduced by dico, is very important because it can be a criterion of the pragmatic value to attribute to the utterance. Morphosyntactically the quoted speech can be an infinitive clause, a juxtaposed clause (with imperative mood or indicative mood (present and future)), a dependent clause with subjunctive, ${ }^{21}$ an accusative, an adverb or another case. Our corpus proves that there is a correlation between the pragmatic and enunciative interpretation of the quoted speech, introduced by dico, and the morphosyntactic class of this same speech.

Finally, besides the discursive context and the morphosyntactic class of the quoted speech, a last parameter should be considered, namely the position of dico on the syntagmatic axis in comparison with the quoted speech.

A triple relation is established between the position of dico, the morphosyntactic class of the quoted speech and the pragmatic-enunciative interpretation to attribute to this reported speech. Consequently the autonymous interpretation of the quoted speech often coincides with juxtaposition / accusative / other cases, on the one hand, and inserted position of dico, ${ }^{22}$

\footnotetext{
dico are distributed in this way: 100 occ. (archaic period I), 028 occ. (archaic period II), 158 occ. (archaic period III, limited to Cic. Catil., Dom., Har. resp., Leg. agr., Prov., Verr. and all the letters), 016 occ. (Augustan Age (= period IV)), 120 occ. (Julio-Claudian dynasty (= period V)), 022 occ. (Flavian Age (= period VI)).

${ }^{1}$ See (2a). The notion of "diaphonic repetition" (= fr. "reprise diaphonique") has been introduced by Roulet (1985: 71), quoted by Rosier (2008: 31). In verbal interaction, a locutor Y reacts to the utterance of his allocutor (= locutor X): so he repeats an unit of this speech - considered as pragmatic connective - and reintegrates it in his own utterance in order to indicate his point of view (pragmatic effect).

${ }^{20}$ For more examples, see Taous 2016: 13-19.

${ }^{21}$ For the opposition between paratactic clause and hypotactic clause, see Sznajder 1996. For the detail of numbers of the morphosyntactic classes of the quoted speech, see Taous 2016: 19.

${ }^{22}$ Quoting speech (i. e. the dico form) can be prepositional (i. e., before the quoted speech (= fr. "positionnement
} 
on the other hand. The "over"-enunciative interpretation (or emphatic and contrastive interpretation) coincides with the infinitive clause / dependent clause with subjunctive / adverb, ${ }^{23}$ on the one hand, and the prepositional position of dico, on the other hand.

In the following table, we have selected some examples from Plautus, Cicero and Seneca, ${ }^{24}$ in order to illustrate the linguistic relations indicated supra. We have chosen the three morphosyntactic classes which more often coincide with the autonymous interpretation, that is to say the juxtaposed clause, the accusative ${ }^{25}$ and the non-accusative case forms. The gathered data allow evaluating the degree of predictibility of the semantico-pragmatic interpretations of the quoted speech (over-enunciative; autonymous) in comparison with its own morphosyntactic class (juxtaposed clause; accusative; non-accusative case):

\section{TABLE 1}

Semantico-pragmatic interpretation and morphosyntactic form of the quoted speech (number of occ.)

\begin{tabular}{|c|c|c|c|c|c|c|}
\hline Writer & & & & & & \\
\hline & $\begin{array}{l}\text { "over"- } \\
\text { enunciative }\end{array}$ & autonymous & $\begin{array}{l}\text { "over"- } \\
\text { enunciative }\end{array}$ & autonymous & $\begin{array}{l}\text { "over"- } \\
\text { enunciative }\end{array}$ & autonymous \\
\hline $\begin{array}{l}\text { Juxtaposed } \\
\text { clause }\end{array}$ & 14 & 01 & 04 & 09 & 22 & 06 \\
\hline Accusative & 03 & 06 & 02 & 12 & 10 & 21 \\
\hline $\begin{array}{l}\text { Non-accusative } \\
\text { case forms }\end{array}$ & 01 & //// & 03 & 06 & /I/I & 20 \\
\hline
\end{tabular}

The data collected for the three writers confirm that the dico form governing an accusative is to interpret as an autonymous marker in $2 / 3$ of the examples. Then, the examples for the "over"-enunciative interpretation are due to cataphoric phenomena: the accusative, cataphoric, announces the message content which often is an infinitive clause from a morphosyntactic point of view.

So we can also explain the frequency of juxtaposed clauses with the "over"-enunciative interpretation, especially in Plautus' and Seneca's examples (see 14 occ. and 22 occ.). The juxtaposition with cataphoric reference constitutes a borderline case, because it is used in the two semantico-pragmatic contexts. In fact the speaker highlights his utterance (emphatic value) and also stresses this cataphoric "production" introducing his speech (autonymous value). Two tendencies co-exist in the corpus, when the dico form is inserted between the cataphoric adverb and the juxtaposed clause. So the semantic value of the adverb is essential to determine the semantico-pragmatic orientation to give to this self-quotation. In the first

en prolepse")), postposed (i. e., after the quoted speech (= fr. "positionnement en analepse")) or inserted (= fr. "positionnement par insertion"). With respect to this French terminology, see Cerquiglini 1981: 25 and Taous 2016: 10-11.

${ }^{23}$ Concerning the fact that juxtaposition with cataphoric reference constitutes a borderline case in this configuration, see infra. For the methodological detail, see Taous 2016: 20-23.

${ }^{24}$ For the reason why these Latin writers have been selected, see Taous 2016: 8-9. The examples come from Brepols' web site, which integrates several data banks like LASLA. See on http://clt.brepolis.net.janus.biu.sorbonne.fr/llta/Default.aspx (accessed 27 August 2013).

${ }^{25}$ When it is not considered as a complement like uera or uerbum. 
tendency, the adverb has a discourse role: as cataphoric, it announces the message content and retakes the utterance into the discourse coherence; in the second tendency, cataphora is implicit, because it is satisfied by the context. That is why the adverb (or the adverb phrase) does not announce any message content, but gives some indications about the modus (see Cic. Dom. XCVI: maxuma uoce dico), speaking time (see Cic. Verr. II V 140: breuissime... dico) and iterative aspect of the speech (see Cic. Att. XIII 25, 3: etiam atque etiam dico) or value judgment of the speaker concerning his utterance (see Cic. Catil. I 3: dico aperte, Cic. Att. VI 1, 3: plane dico...).

Finally, we can see that Cicero and Seneca often use dico with a non-accusative case form. This syntactic rule, which seems very different from the syntactic convention of usage with dicere, is an overt sign indicating that dico is an autonymous marker in these configurations. Some occurrences have been difficult to interpret, especially when there was a prepositional phrase with de + ablative or with a spatial meaning. We have considered three criteria as decisive: in the first we have decided to consider all the context, especially in the (non-)utilization of auto-diaphonic repetitions or words referring to the spatiotemporal setting; in the second one (syntactic), we have considered that the prepositional phrase was to interpret either as a complement governed by the verb (autonymous interpretation), or as an adverbial stressing the hic (et nunc) of the speaker and thus taking the utterance in his sphere (in (3a), see hodie, adsunt). So dico should be interpreted as over-enunciative. The last criterion, semantic, results from the syntactic interpretation: dico does not mean "I am saying", but "I am talking" / "I am saying this". In the table 2, we have tried to summarize the three linguistic criteria from the examples quoted in (3):

(3)

a. Cic. Dom. XXXIV:

Videsne me non radicitus euellere omnis actiones tuas neque illud agere, quod apertum est, te omnino nihil gessisse iure, non fuisse tribunum plebis, hodie esse patricium? Dico apud pontifices, augures adsunt.

b. Sen. Epist. XIV 11 :

Ad philosophiam ergo confugiendum est; hae litterae, non dico apud bonos sed apud mediocriter malos infularum loco sunt.

TABLE 2

Some difficult examples: Synthesis of linguistic criteria.

About dico apud...

\begin{tabular}{|c|c|c|}
\hline & $\begin{array}{l}\text { Autonymous } \\
\text { interpretation }\end{array}$ & $\begin{array}{c}\text { "Over"-enunciative } \\
\text { interpretation }\end{array}$ \\
\hline \multicolumn{3}{|c|}{ 1. Contextual criterion } \\
\hline \multirow[t]{2}{*}{ Auto-diaphonic repetition } & $\begin{array}{l}\text { YES } \\
\text { See (3b): APVD bonos sed } \\
\text { APVD mediocriter malos }\end{array}$ & SOMETIMES \\
\hline & & YES \\
\hline
\end{tabular}




\begin{tabular}{|c|c|c|}
\hline Spatiotemporal setting & NO & See (3a) : hodie, adsunt \\
\hline \multicolumn{3}{|c|}{ 2. Syntactic criterion } \\
\hline $\begin{array}{c}\text { Complement governed by } \\
\text { dico }\end{array}$ & YES & NO \\
\hline Adverbial & NO & YES \\
\hline & 3. Semantic criterion \\
\hline "say 'X'..." & YES & NO \\
\hline "talk" & NO & YES \\
\hline
\end{tabular}

So the three Latin writers approximately confirm that there is an interrelation between morphosyntactic class of the quoted speech, position of dico and semantico-pragmatic interpretation. However some occurrences constitute borderline cases, so that we agree with Reix (1981: 279), when he says that "the natural metalanguage is our current and ordinary conversation about the language" and that, "in the verbal interaction, we are compelled to comment on our speech, especially in the frame of reference and signification" (we have stressed some words) ${ }^{26}$ So "over"--utterance act and autonymy do not constitute dichotomous notions. That is why it is finally difficult to evaluate with precision the place of autonymy in the self-quotation. We will only say that autonymy plays a major role, so that we have decided to describe precisely the autonymous dico from examples drawn from the archaic period to the Flavian period.

\section{Dico and the autonymous interpretation of the quoted speech}

\section{1. Autonymous uses and pragmatics}

Dico as an autonymous marker often appears in epistolary and philosophic genres, although Livius and, above all, Quintilianus use autonymous dico here and there. In these uses, locutors want to explain or confirm a formulation, considered opaque by them if this is not emphasized by a metadiscourse comment, or finally, to stress a witty remark (see (7) for an example in comedy). In Latin (conforming to what is observed in other languages of the world), the word quoted in autonymy is various, not only as semantic category ((in)animate), but also as syntactic class (noun, inflected verb, adverb, phrase, clause...). The syntactic function of dico is different, because it depends on the context of the occurrences: either dico constitutes the verbal nucleus of the clause and should be considered as verbal predicate (see (4a) and (4b)), or it is inserted into a clause which possesses its own inflected verb; in these conditions, dico indicates a break in syntagmatic chain, a change of enunciative level. Indeed dico introduces a comment clause, a parenthetical clause which tries to justify the relevance of selected words or clauses, used in usage, and proposes a metalinguistic analysis of these units (see (5a) and (5b)): ${ }^{27}$ the speaker slides from a linguistic plane, where the meaning of words

\footnotetext{
${ }^{26}$ See Reix (1981: 279): "le métalangage naturel est donc notre discours familier quotidien sur le langage"; "dans la communication, nous sommes obligés de commenter nos dires, notamment dans le cas de désignation et de signification".

${ }^{27}$ Concerning dico and its role in parenthetical clauses, see Charnavel (2007: 100-108; 172).
} 
is understood in usage, to a metalinguistic plane.

(4)

a. Sen. rhet. Suas. V 4:

Si uenerit, uincemus. Hoc non est diu colligendum: de eo dico VINCEMVS quem uicimus. Sed ne ueniet quidem.

b. Sen. Epist. IX 5:

Ita sapiens se contentus est, non ut uelit esse sine amico, sed ut possit. Et hoc, quod dico POSSIT, tale est: amissum aequo animo fert. Sine amico quidem numquam erit.

(5)

a. Cic. Prov. XVIII:

An Ti. Gracchus - PATREM dico, CVIVS utinam filii ne degenerassent a grauitate patria! - tantam laudem est adeptus, quod tribunus plebis solus...?

b. Cic. Verr. II 4, 6:

Nuper homines nobiles eiusmodi, iudices - sed quid dico NVPER? Immo uero MODO AC PLANE PAVLO ANTE - uidimus qui...

After reading various examples, we have noticed that dico as an autonymous marker generally coincides with auto-diaphonic repetitions (see (4) and (5b), for example) or is used immediately after the word, utilized in usage (see (5a)). According to Reix (1981: 279), a speaker chooses an autonymous procedural step, because he wants to clarify a reference, regarded as ambiguous, or to develop a signification, in order to be sure that the allocutor really grasps all the relevance of the selected words. In a comment unit concerning the reference (see (5a)), the autonymy is utilized to disambiguate and so possesses a pedagogical scope where the receiver determines the metadiscourse of the locutor. By contrast, in a comment unit concerning the signification, the explicature allows the speaker to reveal to the allocutor the relevance of the selected words. So the speaker draws the attention of the receiver to the subtlety of his utterance, with this idea that, in discourse, each chosen word signifies and is efficient. By theses different uses the speaker works on ethical proof.

On this matter, the example (4b) is interesting to analyze. Thus Seneca seems to stress no more the selected lexeme (the verb posse) than the chosen mood (subjunctive), while the indicative is expected. Indeed, with the causal structure non quod/ut (+ subjunctive), sed quia/ut (+ indicative), the verb used in the second part of the causal clause is inflected in the indicative. Seneca explicitly justifies the use of the subjunctive possit and guides the reader towards an interpretation as potential or counterfactual, as it is suggested at the end of the extract (Sine amico quidem numquam erit): the subjunctive contains a semantically full value; thus we must not consider it as a syntactic use, determined by the hypotaxis. In fact this metadiscursive comment clause allows conceptualizing the philosophic idea according to which the sage (sapiens), alone, is still with his friends and so is connected with the discourse coherence and makes the Stoic paradox evident. By contrast, Cicero's autonymous comment units (nouns, phrases or clauses) are very different: they are not comments, but excursus, that means metadiscursive digressions where the speaker breaks the chain of his utterance and adds an occasional and (so-called) insignificant remark. 


\section{2. Autonymous uses and repetitions: anaphoric or diaphonic function?}

We have considered that the criterion of repetition was very important to recognize dico as autonymous marker. So the procedural step of analysis, generally used to explain anaphoric reference, will be utilized here: we must identify anaphoric substitutes and clarify the semantic relationship between these substitutes and their antecedents. Nevertheless, it is a little inexact to claim that anaphoric repetition is the same thing as repetition in the autonymous contexts, because this inaccuracy hides one of specificities of the autonymous discourse: the importance to the metalinguistic plane. Indeed, anaphora (in the strict sense) is connected with the topical and textual coherence of a speech and is at the linguistic level. By contrast, auto-diaphonic repetitions are not only correlated to anaphora, but above all they add the idea that there is an enunciative disconnection: if there is repetition, this is connected with the metadiscourse.

Auto-diaphonic repetitions have a special status which can explain the morphosyntactic diversity of the words quoted in autonymy and the differences of syntactic rection, in comparison with the grammatical usage. Indeed, with dico infinitive clauses are expected, dependent clauses with subjunctive (with $u t$ or interrogative word), accusative whose semantic category refers to the discourse ${ }^{28}$ and prepositional phrases with de + ablative. But when it is an autonymous marker, dico can govern not only a noun inflected in the accusative, even if it pertains to the animate semantic category (see (5a) and (6a)), or in another case form (see (6b)), but also an adverb (see (5b)) or an inflected verb, juxtaposed (see (4) and (6c)):

(6)

a. Liv. XXXII 21, 13:

Cur igitur nostrum ille auxilium absens petit potius quam praesens NOS, socios ueteres, simul ab Nabide ac Romanis tueatur? NOS dico? Quid ita passus est Eretriam Carystumque capi?

b. Scrib. Larg. Compos. XXII 23:

His fere utor primis diebus collyriis non sine CETERIS AVXILIIS, prout res postulat, ABSTINENTIA dico, SANGVINIS DETRACTIONE.

c. Cic. Epist. XII 3, 1:

Primum in statua quam posuit in rostris inscripsit "Parenti optime merito", ut non modo sicarii sed iam etiam parricidae IVDICEMINI. Quid dico IVDICEMINI? IVDICEMVR potius.

Concerning the repetitions, the Latin writers of the corpus offer two tendencies: either the speaker produces a first utterance which is literally repeated, so that he justifies and explains his terminological choices (see (4a), (4b), (5b), (6a) and (6c)), or the speaker develops one of the words of the previous utterance differently, so that he clarifies his idea or

\footnotetext{
${ }^{28}$ So contrast me dico / Capuam dico with uera dico: we can identify the non-autonymous uses of dico by the semantic proximity between the accusative (uerbum, uera...) and dicere. Nevertheless, an animate accusative can be governed by dicere, but the meaning is "honour somebody".
} 
disambiguates an homonymic unit (see (5a) and (6b)). The way of repeating - literally or differently - is very important to grasp the intentions of the speaker. So in a literal repetition (i. e. the prototype $\ldots X$, dico $X$, quia...), dico contains a progressive aspect ( $\mathrm{X}$, I am saying - here and now $-X$, because... »). The utterance introduced by dico constitutes a break, a temporal stop where the speech spreads in a reflexive parenthesis about the language. ${ }^{29}$ Thus the intent of the locutor is to stress the relevance of his lexical selection (indicate a syllepsis, a witticism...): thanks to the explanation and explicature of the speaker, the receiver reads behind the word and understands that the speech is pre-built and so is not insignificant. In some examples, dico again introduces a correction (see (5b), (6a) and (6c)): at the sentence level, the epanorthosis always coincides with an interrogative sentence (like quid dico... X?); at the pragmatic level, these corrections confirm the intellectual honesty of the locutor.

But in a non-literal repetition (i. e. the prototype ... X, dico $Y$ ), dico contains a desiderative aspect and indicates a pedagogic precision (' $\mathrm{X}$, I mean $\mathrm{Y}$ '). In these configurations, dico can change its syntactic category and after a derivation by conversion be grammaticalized as an adverb. The French translations 'c'est-à-dire', 'à savoir' would confirm this analysis. In the following table, we propose to condense our different remarks:

TABLE 3

Semantico-pragmatic specificities of dico as autonymous marker

\begin{tabular}{|c|c|c|}
\hline $\begin{array}{c}\text { Point of incidence } \\
\text { of the metadiscourse }\end{array}$ & Comment on the reference & $\begin{array}{c}\text { Comment on the } \\
\text { signification }\end{array}$ \\
\hline $\begin{array}{c}\text { (Proto)type of the } \\
\text { autodiaphonic repetition }\end{array}$ & $\begin{array}{c}\text { Different / no-literal } \\
(\ldots X, \text { dico } Y \ldots)\end{array}$ & $\begin{array}{c}\text { Literal } \\
(\ldots X, \text { dico } X \ldots)\end{array}$ \\
\hline Aspectual value of dico & Desiderative & Progressive \\
\hline Intents of the locutor & $\begin{array}{c}\text { Pedagogic intent } \\
\text { (clarify) }\end{array}$ & $\begin{array}{c}\text { Ethic intent } \\
\text { (read under the word) }\end{array}$ \\
\hline
\end{tabular}

We can again specify the semantico-referential behavior of the non-literal autodiaphonic repetitions. Indeed, the quoted speech can use a characterization which clarifies the antecedent (see ferreo in (7)) or paraphrase words referring to a semantic relationship between...

... meronym/holonym (see, in (8a), in portum (part) paraphrased in in urbem (all)),

... hyperonym/hyponym (see $\mathbf{( 8 b )}$ : the ablative praepotentibus uiris is repeated by principibus, regibus),

... generic/specific (see (9)). In this last configuration, a nominal relative clause, uttered at first, can be specified (see (9b) and (9c)):

(7) Plt. Curc. 690-691:

Delicatum te hodie faciam CVM CATELLO ut accubes, FERREO ego dico...

\footnotetext{
${ }^{29}$ Concerning the notion of opacification defined as the interposition of metalinguistic units, see Charnavel (2007: 286) quoting Authier-Revuz.
} 
(8)

a. Cic. Verr. II 5, 96:

... statim sine ullo metu IN IPSVM PORTVM penetrare coeperunt. Cum IN PORTVM dico, iudices, - explanandum est enim diligentius eorum causa qui locum ignorant - IN VRBEM dico ATQVE IN VRBIS INTVMAM PARTEM uenisse piratas.

b. Sen. Benef. V 4, 2:

Nam si turpe est beneficiis uinci, non oportet A PRAEPOTENTIBVS VIRIS accipere beneficium, quibus gratiam referre non possis, A PRINCIPIBVS dico, A REGIBVS, quos eo loco fortuna posuit, ex quo largiri multa possent pauca admodum et inparia datis recepturi.

(9)

a. Cic. Att. I 12, 2:

LIBERTVM ego habeo SANE NEQVAM HOMINEM, HILARVM dico, ratiocinatorem et clientem tuum.

b. Cic. Leg. agr. II 95:

HAEC QVI PROSPEXERVNT, MAIORES NOSTROS dico, Quirites, non eos in deorum immortalium numero uenerandos a nobis et colendos putatis?

c. Sen. Dial. VII 15, 6:

Quae autem dementia est potius trahi quam sequi? Tam me hercules quam stultitia et ignoratio condicionis est suae dolere, quod deest aliquid tibi aut incidit durius, aeque mirari aut indigne ferre EA, QVAE TAM BONIS ACCIDVNT QVAM MALIS, MORBOS dico, FVNERA, DEBILITATES ET CETERA EX TRANSVERSO IN VITAM HVMANAM INCVRRENTIA.

We can see that the two occurrences of dico in (8a) are different: in the first one, dico suggests a metadiscourse referring to the relevance of the signification (from there, the literal autodiaphonic repetition), whereas, in the second one, dico introduces a metadiscourse on the reference: dico opens a pedagogic parenthesis. The speaker repeats the prepositional phrase in portum and reveals all the stakes and dangers correlated to this invasion (in portum $=$ in urbem). The first utterance, non-autonymous (in ipsum portum), announces some constituents of the last reformulation (in urbis intumam partem). So dico explicitly introduces the metadiscursive digression which must be understood as a simple epanorthosis, in the beginning, but as a political remark, at the end.

\section{3. The case particularities of the word used in autonymy with dico}

Ernout and Thomas (2002 [1953]: 135) notice that dico can be used in a sentence containing its own syntactic organization. Dico often repeats the unit with the case form in which it is inflected in the sentence (see (6a), (6b), (7), (8a) and (9a)), ${ }^{30}$ except with the

\footnotetext{
${ }^{30}$ Other examples: Cic. Att. XVI 15, 5 (with the dative); Liv. V 3, 9 (with the adnominal genitive); Liv. XL 27, 11 (with a dative governed by occurret); Sen. rhet. Contr. I, praef., 10 (with a dative governed by placeat); Sen. rhet. Contr. III, praef., 12 (prepositional phrase); Quint. Inst. IV 2, 79 (with the ablative of the comparative).
} 
nominative case (see (10a)): in this configuration, dico repeats the unit with accusative, the usual case expected with this verb in its non-autonymous uses.

The examples of the corpus approximately confirm the Ernout and Thomas' remarks (see (10)), while some nominative / accusative case forms are ambiguous and do not allow any sound conclusion. ${ }^{31}$ The example (10c) is interesting to consider, because it indicates the differences of syntactic behavior between dico and inquam concerning the syntactic rules: so, dico used as an autonymous marker has not reached the degree of grammaticalization of inquam, since it keeps its verbal prerogatives (rection with accusative), whereas inquam, higher on the scale of grammaticalization, ${ }^{32}$ seems to become an adverb of evidentiality:

(10)

a. Cic. Att. 4, 16, 8:

Itaque CAESARIS AMICI (ME dico ET OPPIVM, disrumparis licet) in monumentum illud quod tu tollere laudibus solebas [...] contempsimus sexcenties sestertium.

b. Cic. Att. XVI 15, 5:

Me RES FAMILIARIS mouet. REM dico? Immo uero EXISTIMATIO.

c. Cic. Att. VI 2, 4:

His ego duobus generibus facultatem ad se aere alieno liberandas aut leuandas dedi, uno quod omnino NVLLVS in imperio meo SVMPTVS factus est (NVLLVM cum dico non loquor i $\varepsilon \varepsilon \rho \beta о \lambda \imath \kappa \tilde{\omega} \varsigma: ~ N V L L V S$ inquam, ne terruncius quidem)...

(11)

a. Cic. Verr. II 4, 25:

Mamertini ME publice non inuitarunt. ME cum dico, leue est.

b. Cic. Epist. I 14, 1:

BREVES litterae tuae - BREVES dico? Immo NVLLAE.

However some examples reveal that it is possible to find the nominative case governed by dico used as an autonymous marker. To the two examples of the corpus ((12a) and (12b)), we can add the text of a tabella defixionis where the locutor indicates the grammaticality of the two syntactic rules (dico with accusative; dico with nominative) and this, on the same syntagmatic chain. In this tablet, the elements in square brackets indicate the philologists' reconstructions from the comparison of five tablets dated from the end of Republic; and concerning the inflectional ending the text is categorical: nominative (or vocative?) and accusative co-occur in the same utterance:

\footnotetext{
${ }^{31}$ See (11). In (11a), is the second occurrence of the accusative me governed by dico or does dico literally repeat the accusative me, governed by inuitarunt in the non-autonymous utterance? In the same way, in (11b), breues can be interpreted either as accusative governed by dico or as nominative repeated by dico with the case form of the non-autonymous utterance. The nominative nullae would confirm this last interpretation and would reveal that the nominative with dico is possible, despite (10b), of similar structure (Rem dico? Immo uero existimatio).

${ }^{32}$ The grammaticalization of inquam, detectable from syntactic indications (nominative $v s$ accusative), has been facilitated by the defective conjugation of this verb and by its very conditioned uses, unlike dico, very frequent and usual (as shows its future in Romance languages).
} 
a. Cic. Fam. IX 22, 3:

Cum loquimur "terni", nihil flagiti dicimus; at cum "bini", obscenum est? Graecis quidem, inquies. Nihil est ergo in uerbo, quoniam et ego Graece scio et tamen tibi dico "BINI", idque tu facis quasi ego Graece, non Latine, dixerim.

b. Quint. Inst. VI 1, 24:

Adfert in his momentum et aetas et sexus et pignora, LIBERI, dico, ET PARENTES ET PROPINQVI.

c. Tabellae deuotionis (A. Ernout 1916: 100 A, 1-13 = W. Sherwood Fox 1912: A, 1-13, pp. 19-21):

[B]ona pul[chra P]roserpina, Plutoni[s

u]xsor, seiue [me SALVIAM] deicere oportet,

eripias salu[tem], corp[us], colorem, uires,

uirtutes Au[on]ia[es] [...]

[...] [Qu]are hanc uictimam

[tibi] trado, [Proserpin]a, seiue me

[PROS]ERPINA, se[iue me ACH]ERVOSIAM dicere

[opo]rtet...

We will venture the hypothesis that the text of the tablet certainly offered a vocative (Proserpina) and an accusative (Acheruosiam). The accusative form, because it suggests considerable syntactic dependency, would be comparable to the role of the subjunctive in comparison to the indicative and so would be less spontaneous than a vocative. Indeed the change of the vocative into an accusative indicates the importance of the syntactic dependency on the verbal form dicere. It is possible that the nominative-vocative with dico has been used for notifying in writing the intonation of the appellative. Also, the nominativevocative would be used whenever the intent would be to imitate the intonation contour of the utterance. In these conditions, Latin speakers would have attributed to these units in nominative-vocative a rising intonation, non-existent in the frame of the accusative.

The use of nominative and vocative cases, indicated here, is not an isolated

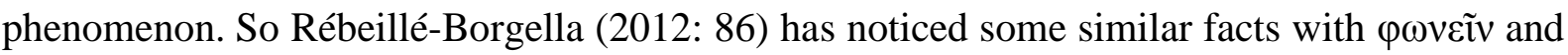
uocāre, in the New Testament (Johan. XIII 13): the quoted examples seem syntactically surprising, since from a referential point of view the element in the accusative ( $\mu \varepsilon$ and $m e$ in the examples) is connected with an object complement in the vocative (magister et Domine)

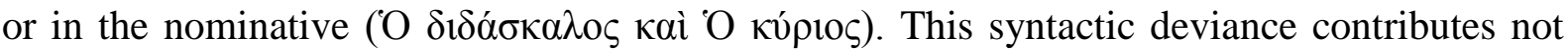
only to indicate the autonymous utilization, but also to confer on the utterance a particular value: the utilization of nominative / vocative cases in texts which are embedded in the oral form and which consider the utterance act as magic (see the Tabellae defixionis) and efficient

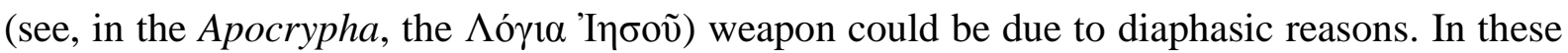
specific and particular texts, it was necessary to imitate in writing the uttered word, in order to give back all its performativity. The phenomenon could have been generalized in the less symbolically charged texts.

Then a confusion between diverse cases could have been made (see, perhaps, Quintilianus in (12b)) and the vocative-nominative could no longer have been saved to imitate the rising intonation of the locutor but only for syntactic reasons: in some contexts, the 
autonymous unit was coreferential with a nominative (here, pignora) and so it has been inflected in the case form of the word with which it was connected (namely, in the nominative), with dico as adverb. The suprasegmental value, originally attributed to the vocative, has progressively disappeared because of the morphological neutralization between vocative and nominative; vocative may have been reinterpreted as nominative (no-marked case form) which has been saved, when the word with which it was coreferential was subject of the sentence (see pignora in our example). In our opinion Quintilianus deliberately selects the nominatives liberi and propinqui, whereas he could have used the accusative, since the neuter pignora, noun expanded by liberi, parentes and propinqui, is morphologically ambiguous: so Quintilianus wittingly selects a nominative, because liberi, propinqui and parentes are subjects of adfert (agreement with the latter) too. Dico is thus completely grammaticalized, since it has lost the verbal prerogatives which it still kept in these configurations, namely with an expanded nominative.

\section{Conclusion}

While this paper is not exhaustive, we have tried to prove the original behavior of dico as autonymous marker. The diverse examples have indicated that dico was used for introducing a digression or a metadiscursive comment. Two pragmatic attitudes have been shown and correlated to precise morphosyntactic features: when the point of incidence of the metadiscourse is connected with a comment on the reference, dico contains a desiderative aspect ("I mean" / "I want to say") and coincides with a no-literal autodiaphonic repetition. The speaker thus tries to clarify his idea in order to be clearly understood. But when the point of incidence of the metadiscourse is connected with a comment on the signification, dico so contains a progressive aspect and the speaker comments on the relevance of the word used in autonymy or, by contrast, in an intellectual honesty, he tries to correct his utterance. This second configuration is to connect with a literal autodiaphonic repetition where the speaking time seems to stop and where the linguistic construction is made at the same time as the speech is uttered.

For this reason, the verb aio, symbolically very charged, could not be used in these autonymous configurations: indeed, the trend towards the grammaticalization, which ultimately concerns dico in some occurrences, reveals that this linguistic evolution was perhaps less compatible with aio.

\section{Bibliographical references}

Authier-Revuz, Jacqueline. 1984. Hétérogénéité(s) énonciative(s). Langages 73. Les Plans d'énonciation. 98-111.

Bearth, Thomas \& Fennig, Charles. 2015. French-English Glossary of Linguistic Terms, see

01.sil.org/linguistics/glossary_fe/glossary_index.asp?searchlang=b\&search=s\&qu

al=good\&type=all (accessed 13 May 2017).

Brabanter (de), Philippe. 2005. Philosophes du langage et autonymie: une déjà longue histoire. Histoire Épistémologie Langage 27(1). La linguistique baltique. 11-43. 
Carnap, Rudolph. 2002 [1937]. The Logical Syntax of Language, translated by A. Smeaton. Chicago and La Salle: Open Court Classic.

Cerquiglini, Bernard. 1981. La parole médiévale - Discours, syntaxe, texte. Paris: Éditions de Minuit.

Charnavel, Isabelle. 2007. Les énoncés parenthétiques chez Cicéron: syntaxe et pragmatique. Master II, M. Fruyt (ed.). Paris: University Paris IV - Sorbonne.

Colapietro, Vincent M. 1993. Glossary of Semiotics. New York: Paragon House.

Crystal, David. 2003. A Dictionary of Linguistics and Phonetics. Oxford: Blackwell.

Ernout, Alfred. 1916. Recueil de textes latins archaïques. Paris: Klincksieck.

Ernout, Alfred \& Thomas, François. 2002 [1953]. Syntaxe latine. Paris: Klincksieck.

Fleck, Frédérique. 2015. La possibilité d'un îlot. La répétition comme indice de littéralité. In Frédérique Fleck \& Lyliane Sznajder (eds.), Le discours rapporté en latin (2/2), De lingua Latina 11, 1-14. http://www.paris-sorbonne.fr/Numero-11-mai-2015 (accessed 12 April 2017).

Flobert, Pierre. 1975. Les verbes déponents latins. Des origines à Charlemagne. Paris: Les Belles Lettres.

Frege, Gottlob. 1994 [1892]. Écrits logiques et philosophiques, translated by Cl. Imbert. Paris: Le Seuil.

Levinson, Stephen C. 1983. Pragmatics. Cambridge: Cambridge University Press.

Lyons, Johns. 1977. Semantics, vol. 1. Cambridge: Cambridge University Press.

Nicolas, Christian. 2005a. Quel est le statut syntaxique de l'autonyme dans l'énoncé latin? L'exemple des tours $X a b Y$. In Colette Bodelot (ed.), Éléments “asyntaxiques” ou hors structure dans l'énoncé latin, ERGA 9, 93-106. Clermont-Ferrand: Université Blaise Pascal.

Nicolas, Christian. 2005b. La question du genre et du nombre des autonymes en latin. Histoire Épistémologie Langage 27(1), La linguistique baltique. 45-72.

Nöth, Winfried. 1995 [1990]. Handbook of Semiotics. Bloomington: Indiana University Press.

Quine, Willard Van Orman. 1981 [1940]. Mathematical Logic, revised edition. Cambridge: Harvard University Press.

Rébeillé-Borgella, Marie. 2012. Vocare, Vocatio, leurs préverbés et préfixés: étude sémantique. PhD. Chr. Nicolas (ed.). Lyon: University Jean Moulin (Lyon 3).

Reix, André. 1981. Compte-rendu de "Linguistique. Le métalangage. Étude linguistique du discours sur le langage, Fr. François - J. Rey-Debove (dir.)". Revue Philosophique de Louvain 79(42), série 4. 278-280.

Rey-Debove, Josette. 1971. Notes sur une interprétation autonymique de la littérarité: le mode du 'comme je dis'. Littérature 4. 90-95.

Rosier, Laurence. 2008. Le discours rapporté en français. Paris: Ophrys "L’essentiel”.

Rosier-Catach, Irène. 2003. La suppositio materialis et la question de l'autonymie au Moyen-Âge. In Jacqueline Authier-Revuz, Marianne Doury \& Sandrine Reboul-Touré (eds.), Parler des mots. 21-55. Paris: Presses de la Sorbonne nouvelle. For a complete version, see www.cavi.univ-paris3.fr/ilpga/autonymie/theme1/rosiercatl.pdf, 1-33 (accessed 14 March 2017).

Sherwood Fox, William. 1912. The Johns Hopkins Tabellae defixionum. [Special issue]. The American Journal of Philology 33(1). 1-9 and 11-68. 
http://www.jstor.org/stable/25163769 (accessed 13 June 2015).

Sznajder, Lyliane. 1996. Construction paratactique et sermo cotidianus dans la langue de Plaute. In Jacqueline Dangel \& Claude Moussy (eds.), Les structures de l'oralité en latin, 167-180. Paris: PUPS.

Taous, Tatiana. 2016. L'autocitation en latin ou lorsque le locuteur devient son propre 'rapporteur'. Étude des structures du type dico... / aio .... Vita Latina 193-194. 5-28.

Wales, Katie. 1989. A Dictionary of Stylistics. London: Longman. 